\title{
Colonic interposition in a woman with attenuated familial adenomatous polyposis: Does the location of the colon affect polyp formation?
}

\author{
Melanie D Beaton MD FRCPC ${ }^{1}$, Brian Taylor MD FRCSC ${ }^{2}$, David Driman MD FRCPC ${ }^{3}$, \\ Peter Ainsworth PhD FRCPC ${ }^{4}$, Paul C Adams MD FRCPC ${ }^{1}$
}

\begin{abstract}
MD Beaton, B Taylor, D Driman, P Ainsworth, PC Adams. Colonic interposition in a woman with attenuated familial adenomatous polyposis: Does the location of the colon affect polyp formation? Can J Gastroenterol 2008;22(7):634-636.

Attenuated familial adenomatous polyposis (AFAP) is a rare but well-established cause of colorectal carcinoma and multiple polyps. The present paper describes a case of a woman diagnosed with colorectal cancer at 34 years of age and subsequently found to have AFAP by genetic testing. During infancy, the patient underwent surgical correction of esophageal atresia with colonic interposition. While she had developed adenomatous polyps in her native cecum, there was no evidence of polyps or cancer in the segment of large intestine interposed between her upper esophagus and stomach. Therefore, various environmental differences between the upper and lower gastrointestinal tract may play a role in the expression of AFAP phenotype.
\end{abstract}

Une interposition colique chez une femme atteinte de polypose colique familiale atténuée : L'emplacement du côlon a-t-il une incidence sur la formation des polypes?

\begin{abstract}
La polypose colique familiale atténuée (PCFA) est une cause rare mais bien établie de carcinome colorectal et de polypes multiples. Le présent article décrit le cas d'une femme atteinte d'un cancer colorectal diagnostiqué à 34 ans chez qui on a ensuite découvert une PCFA par dépistage génétique. Pendant la première enfance, la patiente avait subi une correction chirurgicale d'atrésie œesophagienne avec interposition colique. Elle avait des polyadénomes dans le cæcum d'origine, mais aucune trace de polypes ou de cancer dans le segment du gros intestin interposé entre l'œsophage supérieur et l'estomac. Par conséquent, diverses différences environnementales entre le tube digestif supérieur et inférieur peuvent jouer un rôle dans l'expression du phénotype de la PCFA.
\end{abstract}

Key Words: Colonic interposition; Colorectal cancer; Familial polyposis

\begin{abstract}
Colorectal cancer is the third most commonly diagnosed cancer in both men and women. Hereditary colon cancers account for approximately $5 \%$ of these, with familial adenomatous polyposis (FAP) responsible for less than 1\%. Among patients with FAP, $10 \%$ have a milder course of disease with less than 100 colorectal adenomas and a later onset of disease, termed attenuated FAP (AFAP).
\end{abstract}

\section{CASE PRESENTATION}

A patient born with esophageal atresia who underwent surgical correction as an infant is presented. Colonic interposition was performed using a section of large intestine extending from the mid-transverse to the mid-descending colon. She was subsequently found to have a mutation responsible for AFAP.

In her early adult years, two of her siblings were diagnosed with colorectal cancer. One subsequently died of metastatic disease at age 33 years and the other underwent successful surgical resection at 42 years of age. In addition, a paternal uncle was diagnosed with duodenal cancer at 63 years of age and a great aunt also had colorectal cancer.
Because of her family history, the patient had undergone screening colonoscopy at 34 years of age. At that time, she was found to have a rectal adenocarcinoma. In 1998, she underwent subtotal proctocolectomy with cecal anal anastomosis (cecum retained due to patient preference for maintaining a fecal reservoir). The resection specimen pathology findings were those of a moderately differentiated adenocarcinoma, with no evidence of additional adenomatous polyps in the remaining excised colonic tissue (Figure 1). Following her surgery, she underwent annual endoscopic surveillance of the remaining cecal mucosa. Her most recent endoscopy was significant for the finding of eight small ( $3 \mathrm{~mm}$ to $4 \mathrm{~mm}$ ), tubular adenomas with low-grade dysplasia. No metachronous tumours or polyps had been found on previous studies.

Regarding the colonic interposition, this area was also followed with regular endoscopic surveillance by gastroscopy, as well as radiographically (Figure 2). Surveillance has been technically difficult, secondary to the redundancy and angulation of the interposed segment limiting visualization. However, tissue samples from this region repeatedly demonstrated normal

${ }^{1}$ Department of Medicine, Division of Gastroenterology; ${ }^{2}$ Department of Surgery, Division of General Surgery; ${ }^{3}$ Department of Pathology;

${ }^{4}$ Department of Biochemistry, Molecular Diagnostics Laboratory, London Health Sciences Centre, University of Western Ontario, London,

Ontario

Correspondence: Dr Melanie D Beaton, University of Western Ontario, 339 Windermere Road, London, Ontario N6A 5A5.

Telephone 519-663-3344, fax 519-663-3232, e-mail Melanie.Beaton@lhsc.on.ca

Received for publication January 18, 2008. Accepted March 5, 2008 


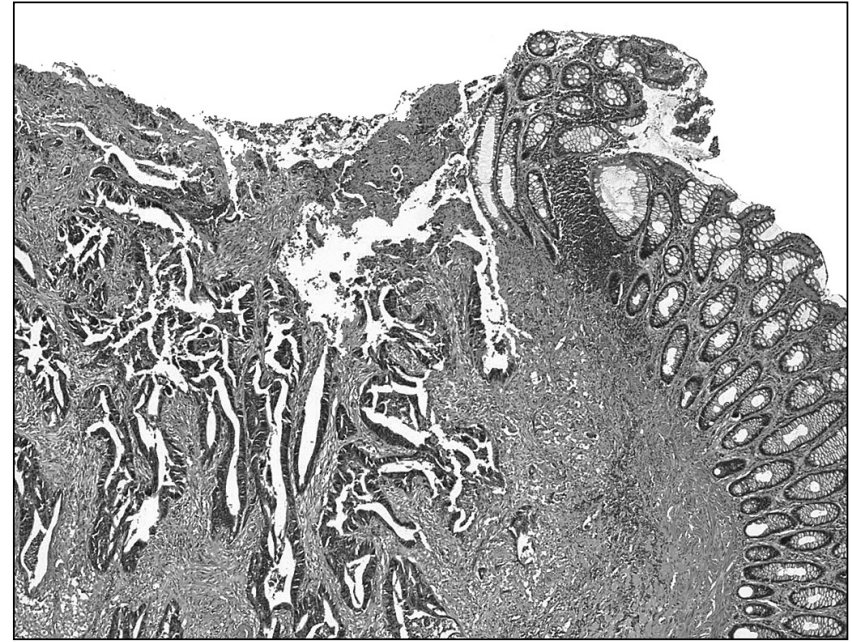

Figure 1) Invasive rectal adenocarcinoma with adjacent normal rectal mucosa

colonic mucosa, with no evidence of dysplasia or malignancy (Figure 3).

\section{DISCUSSION}

There are no previous reports of patients having undergone colonic interposition, and later in life being found to carry a defined genetic mutation associated with a significantly increased lifetime risk of colorectal and other systemic carcinomas. While polyps and cancers in AFAP tend to be found more proximally than in classic FAP, this association is not as striking as in hereditary nonpolyposis colorectal cancer, and rectal carcinoma is not rare $(1,2)$. Also, AFAP has been reported to have an older age distribution than classic FAP. Among patients with AFAP, disease severity and the presence of extracolonic manifestations appears to correlate with the location of the mutation on the adenomatosis polyposis coli (APC) gene (3). However, these associations are not definitive, because inconsistencies and contradictions have been reported $(4,5)$. It is likely that additional genetic and environmental factors play important roles in determining disease manifestations.

The present patient's mutation (APC c.221-2A>G) lies close to the $5^{\prime}$ end of the APC gene. This mutation causes a mis-splicing of the APC gene and consequent shortening of the protein. Splice site prediction software has predicted that this mutation would eliminate the normal splice site and that an abnormal splice site distal to this one would be utilized, resulting in premature termination of translation of the APC protein.

These mutations may exhibit great variability, with some patients reported to have a phenotype similar to that of classic FAP (6). However, mutations within this region are generally associated with a mild polyposis phenotype. Our patient's case appears to be consistent with this, having had a solitary malignancy at the time of her resection and only developing adenomatous polyps a full 10 years later.

The present patient had a documented adenocarcinoma in the setting of a defined mutation of the APC gene. She also developed dysplasia in her remaining intact colon, while the segment of colonic mucosa in her upper gastrointestinal (GI) tract did not show any convincing features of dysplasia or malignancy.

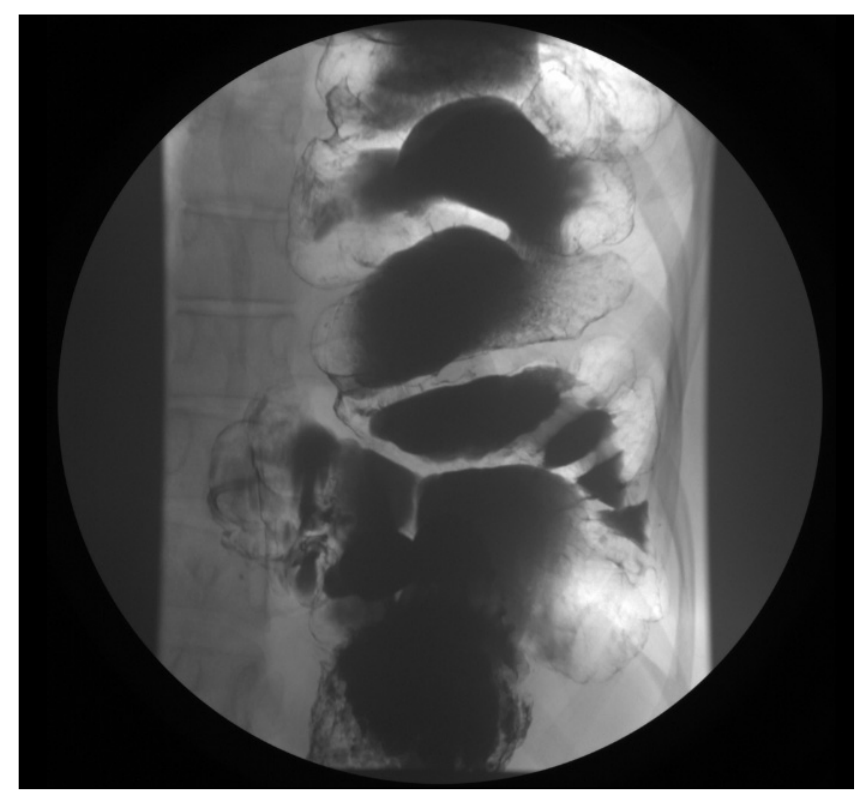

Figure 2) Image from the patient's barium swallow procedure, demonstrating a tortuous colonic mucosal segment

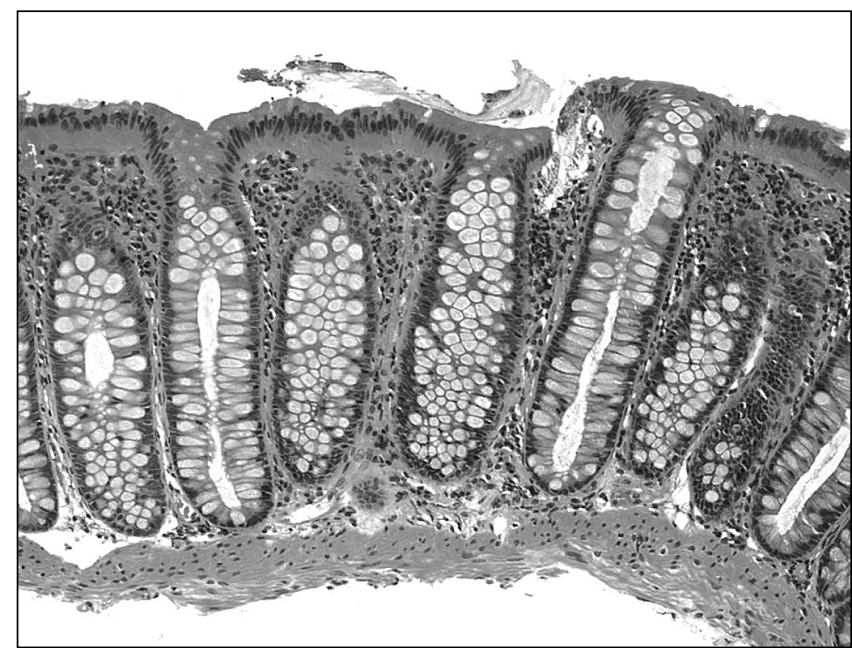

Figure 3) A representative image of one of many biopsies from the interposed colon, showing normal colonic mucosa

This leads us to suspect that the elimination of potentially 'procarcinogenic' factors present in the lower GI tract and/or protective influences in the upper GI tract are involved in the development of cancer in AFAP patients.

In addition to the obvious genetic propensity of AFAP patients to develop cancer, there is also evidence that environmental factors play a potentially important role. One such factor has been hypothesized to be bile acids. The secondary bile acids - deoxycholic and lithocholic acid - are cytotoxic to intestinal epithelial cells (7). These acids induce cell proliferation and have been implicated in carcinogenesis (8). While the majority of evidence supporting the relationship between bile acid toxicity and cancer comes from studies performed in patients with primary sclerosing cholangitis and ulcerative colitis, one of the most common extracolonic manifestations of AFAP is the development of periampullary adenomas and 
carcinomas, suggesting that bile plays a role in the formation or progression of these lesions (9).

A recently published pilot study (10) evaluated the use of ursodeoxycholic acid as an intervention to prevent cancer in patients with FAP. In that small $(n=5)$ group of patients, the investigators were able to attain high concentrations of ursodeoxycholic acid in the bile and noted that this seemed to lower cyclooxygenase- 2 expression, which is a key enzyme regulating cell proliferation.

Colonic bacteria have also been implicated in carcinogenesis. In recent years, there has been a great deal of interest in the potential therapeutic effects of bacteria, as well as their potential role in carcinogenesis. The role of bacteria in the development of colorectal cancer has been demonstrated in the T-cell receptor beta/p53 (11) and interleukin-10 (12) knockout mouse models of carcinogenesis. Under normal conditions, these mice have a significant risk of carcinoma. In the case of the T-cell receptor beta/p53 knockouts, adenocarcinomas appeared in $70 \%$ of animals by four months of age. However, when raised in germ-free conditions, no cancers were seen in these mice. Similarly, in a mouse model of FAP (13), a 50\% reduction in the number of small-bowel adenomas was seen among animals raised in germ-free conditions, suggesting that commensal bacteria may potentiate tumour formation. While a number of bacterial species have been linked to colon cancer in humans (14), the upper GI tract is relatively free of bacterial colonization, with the obvious exception of Helicobacter pylori infection, which has been defined as a group 1 human carcinogen for gastric adenocarcinoma (15).

Although somewhat controversial, stasis of intestinal contents has been hypothesized to be associated with an increased risk for adenocarcinoma (16). This may be particularly relevant in the lower GI tract, where the upper limit of colonic transit time is approximately $72 \mathrm{~h}(17)$, as opposed to the upper GI tract, where clearance of solid contents normally occurs within $1 \mathrm{~h}$ (18). Gastric acid production, particularly in gastroesophageal reflux disease, is an established risk factor for adenocarcinoma of the esophagus (19).

\section{CONCLUSIONS}

While there was no evidence of malignant transformation in our patient's remaining colonic segment, dysplastic changes were documented. This, in the presence of an underlying carcinogenic gene mutation, places her at continued high risk for colorectal cancer. Because AFAP tends to have an older age distribution than classic FAP, it is quite probable that having undergone a proctocolectomy at a relatively young age prevented the development of additional neoplasms in that bowel segment. It also remains possible that this could develop in her neoesophagus in the future (20). She will therefore continue to be followed very closely.

\section{REFERENCES}

1. Cao Y, Pieretti M, Marshall J, et al. Challenge in the differentiation between attenuated familial adenomatous polyposis and hereditary nonpolyposis colorectal cancer: Case report with review of the literature. Am J Gastroenterol 2002;97:1822-7.

2. Matsuo S, Eguchi S, Azuma T, et al. Attenuated familial adenomatous polyposis associated with advanced rectal canacer in a 16-year-old boy: Report of a case. Surg Today 2001;31:1020-3.

3. Nieuwenhuis MH, Vasen HF. Correlations between mutation site in APC and phenotype of familial adenomatous polyposis (FAP): A review of the literature. Crit Rev Oncol Hematol 2007;61:153-61.

4. Rozen P, Samuel Z, Shomrat R, Legum C. Notable intrafamilial phenotypic variability in a kindred with familial adenomatous polyposis and an APC mutation in exon 9. Gut 1999;45:829-33.

5. Walon C, Kartheuser A, Michilis G, et al. Novel germline mutations in the APC gene and their phenotypic spectrum in familial adenomatous polyposis kindreds. Hum Genet 1997;100:601-5.

6. Soravia C, Berk T, Madlensky L, et al. Genotype-phenotype correlations in attenuated adenomatous polyposis coli. Am J Hum Genet 1998;62:1290-301.

7. Martinez JD, Stratagoules ED, LaRue JM, et al. Different bile acids exhibit distinct biological effects: The tumor promoter deoxycholic acid induces apoptosis and the chemopreventive agent ursodeoxycholic acid inhibits cell proliferation. Nutr Cancer 1998;31:111-8.

8. Ochsenkuhn T, Bayerdorffer E, Meining A, et al. Colonic mucosal proliferation is related to serum deoxycholic acid levels. Cancer 1999;85:1664-9.

9. Groves CJ, Saunders BP, Spigelman AD, Phillips RK. Duodenal cancer in patients with familial adenomatous polyposis (FAP): Results of a 10 year prospective study. Gut 2002;50:636-41.

10. Berkhout M, Roelofs HM, Friederich P, et al. Ursodeoxycholic acid intervention in patients with familial adenomatous polyposis: A pilot study. Transl Res 2007;150:147-9.

11. Kado S, Uchida K, Funabashi H, et al. Intestinal microflora are necessary for development of spontaneous adenocarcinoma of the large intestine in T-cell receptor beta chain and p53 double-knockout mice. Cancer Res 2001;61:2395-8.

12. Balish E, Warner T. Enterococcus faecalis induces inflammatory bowel disease in interleukin-10 knockout mice. Am J Pathol 2002;160:2253-7.

13. Dove WF, Clipson L, Gould KA, et al. Intestinal neoplasia in the ApcMin mouse: Independence from the microbial and natural killer (beige locus) status. Cancer Res 1997;57:812-4.

14. Yang L, Pei Z. Bacteria, inflammation, and colon cancer. World J Gastroenterol 2006;12:6741-6.

15. Schistosomes, liver flukes and Helicobacter pylori. IARC Working Group on the Evaluation of Carcinogenic Risks to Humans. Lyon, June 7 to 14, 1994. IARC Monogr Eval Carcinog Risks Hum 1994;61:1-241.

16. Yee YS. Background mucosal changes in colorectal carcinomas. Cancer 1988;61:1563-70.

17. Bouchoucha M, Devroede G, Dorval E, Faye A, Arhan P, Arsac M. Different segmental transit times in patients with irritable bowel syndrome and "normal" colonic transit time: Is there a correlation with symptoms? Tech Coloproctol 2006;10:287-96.

18. Supe AN, Mathur SK, Parulkar BG, Patankar SK, Samsi AB, Tilve GH. Assessment of gastric emptying by radio-nuclide study. J Postgrad Med 1986;32:206-9.

19. Lagergren J, Bergstrom R, Lindgren A, Nyren O. Symptomatic gastroesophageal reflux as a risk factor for esophageal adenocarcinoma. N Engl J Med 1999;340:825-31.

20. Hernegger GS, Moore HG, Guillem JG. Attenuated familial adenomatous polyposis: An evolving and poorly understood entity. Dis Colon Rectum 2002;45:127-36. 


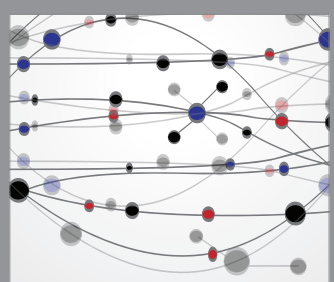

The Scientific World Journal
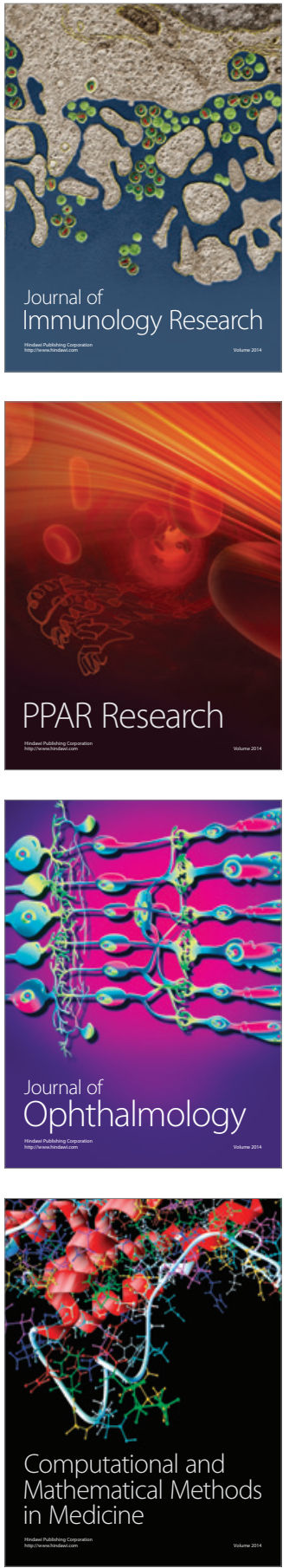

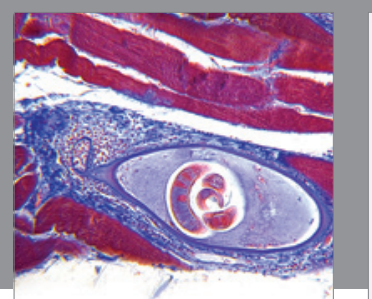

Gastroenterology Research and Practice

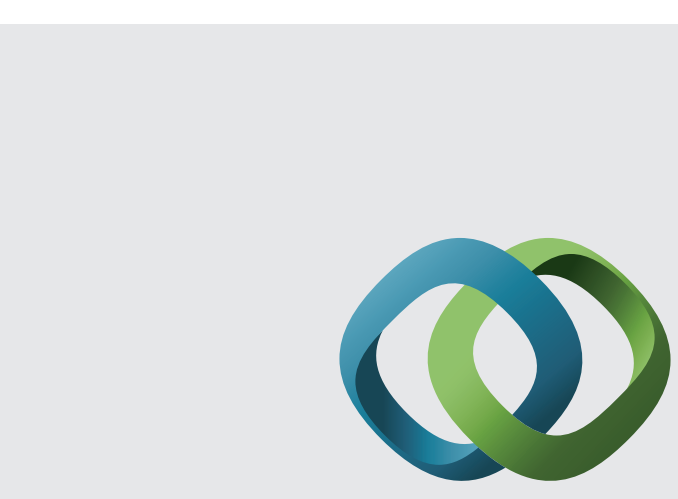

\section{Hindawi}

Submit your manuscripts at

http://www.hindawi.com
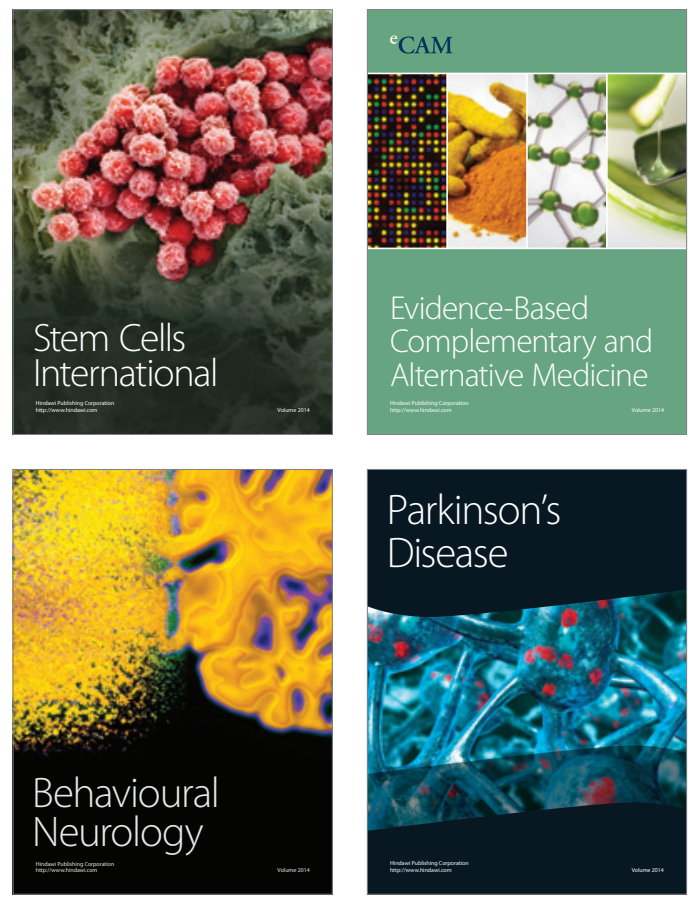
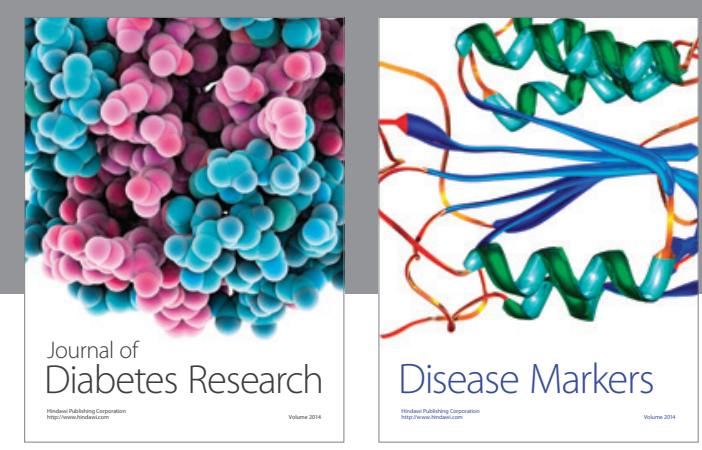

Disease Markers
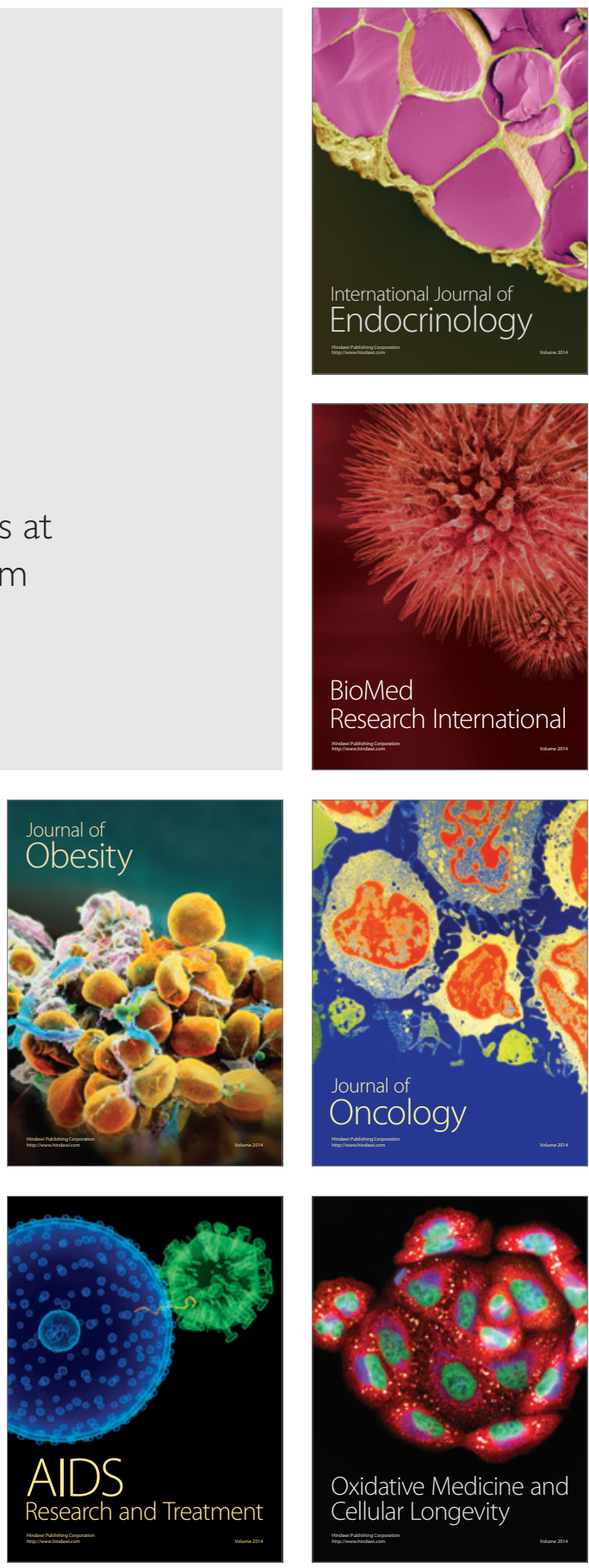